\title{
IDH1 Mutation Is an Independent Inferior Prognostic Indicator for Patients with Myelodysplastic Syndromes
}

\author{
Na Wang Fei Wang Ningning Shan Xiaohui Sui Hongzhi Xu \\ Department of Haematology, Shandong Provincial Hospital Affiliated to Shandong University, Jinan, \\ People's Republic of China
}

\section{Keywords}

IDH1 $\cdot$ IDH2 · Mutation · Myelodysplastic syndromes ·

Prognosis

\begin{abstract}
Background: Genomic sequencing technologies have identified isocitrate dehydrogenase (IDH) mutations in haematological malignancies. The prognostic implications of somatic $I D H$ mutation $(m / D H)$ in myelodysplastic syndromes (MDS) remain controversial. Methods: Mutations in IDH1 and IDH2 were detected using genomic sequencing technologies in 97 patients with MDS. Results: Seven (7.2\%) mutations were identified: 3 in IDH1 (all R132C) and 4 in IDH2 (3 R140Q and 1 R140L). The frequency of mutation was $16.6 \%(2 / 12)$ in refractory anaemia with excess blasts (RAEB)-1 and $14.7 \%$ (5/34) in RAEB-2. IDH1/2 mutations were closely associated with higher bone marrow blast counts (median 10.0 vs. 2.3\%; $p=0.019$ ) and lower absolute neutrophil counts (median $0.44 \times 10^{9} / \mathrm{L}$ vs. $\left.1.21 \times 10^{9} / \mathrm{L} ; p=0.027\right)$. All IDH mutations were mutually exclusive and heterozygous. IDH mutations were not significantly correlated with any specific karyotype. Patients with IDH1 mutations exhibited shorter overall and progression-free survival (OS and PFS; $p=0.039$ and $p=$ 0.042 , respectively), whereas $I D H 2$ mutations did not affect
\end{abstract}

\section{KARGER}

(C) 2017 S. Karger AG, Basel
OS or PFS ( $p=0.560$ and $p=0.218$, respectively). Multivariate analysis indicated that IDH1 mutation ( $p=0.018$; hazard ratio [HR] 4.735; 95\% confidence interval [Cl] 1.299-17.264), karyotype risk ( $p=0.036$; HR 1.619; 95\% Cl 1.033-2.539) and the revised International Prognostic Scoring System risk category ( $p<0.0001$; HR 2.122; 95\% Cl 1.401-3.213) were independent inferior prognostic factors. Conclusions: IDH1 mutation is associated with a poor prognosis.

(c) 2017 S. Karger AG, Basel

\section{Introduction}

Myelodysplastic syndromes (MDS) are a heterogeneous group of clonal haematopoietic stem cell diseases occurring mostly in the elderly. They are characterized by peripheral cytopenias, dysplasia, and ineffective haematopoiesis, and an increased risk of leukaemia transformation $[1,2]$. The median survival of MDS patients ranges from $<6$ months to several years [3]. Environmental exposures to smoking, benzene, and ionizing radiation have been considered risk factors for developing MDS [4]. With the ageing of the population and increasingly severe environmental pollution, the incidence of MDS has been increasing all over the world. 
As a result of genomic sequencing technology, a set of recurrently mutated genes involved in biological and prognostic features have been identified in malignant haematological disorders [5-9]. Among these mutations, the prognostic implications of somatic isocitrate dehydrogenase $(I D H)$ mutation $(m I D H)$ remain controversial. Several studies have recorded adverse outcomes, while others have led to no definitive conclusions or have shown improved results [10-16]. IDH plays an essential role in diverse cellular processes, including metabolism, DNA synthesis, and adaptation to hypoxia [17]. The IDH protein is a key rate-limiting enzyme of the tricarboxylic acid cycle, which normally catalyses the oxidative decarboxylation of isocitrate to $\alpha$-ketoglutarate ( $\alpha-K G$ ) to produce nicotinamide adenine dinucleotide phosphate (NADPH), while mutated forms of the protein instead convert $\alpha-K G$ into 2-hydroxyglutarate $(2-\mathrm{HG})[18,19]$. Recent work has shown that excess 2-HG is involved in changes in methylation patterns in vitro and leads to impaired haematopoietic differentiation [20]. Common recurrent $I D H$ mutations are located in codon 132 in exon 4 of the IDH1 gene and in codon 140 and codon 172 in exon 4 of the $I D H 2$ gene. $I D H 1$ encodes an enzyme that localizes to the cytosol and peroxisomes, while IDH2 encodes an enzyme that localizes to the mitochondria. Although the frequency of $I D H$ mutations in MDS varies from 4 to $12 \%, I D H$ mutations are generally less common in MDS than in acute myeloid leukaemia (AML) [9-11, 21-23]. Additionally, IDH mutations are usually less common in Asian MDS patients than in the Caucasian population [23,24]. In one study, $m I D H$ was found to be less frequent in MDS (5\%) and myeloproliferative neoplasms, but the frequency increased to $20 \%$ of patients at leukaemic transformation. This finding could indicate that $m I D H$ may affect leukaemia transformation during the progression of haematological malignancies, which might then escape from chemotherapy, eventually leading to the relapse or progression of the malignancy. Similarly, we assume that $m I D H$ may play an important role in MDS progression.

In this study, we examined mutations in exon 4 of the $I D H 1$ and IDH2 genes in 97 Chinese patients with MDS, and explored the correlation between IDH1 or IDH2 gene mutations and the survival and progression of MDS.

\section{Methods}

\section{Patients}

A total of 97 patients with MDS (60 males and 37 females) diagnosed according to the World Health Organization criteria (2008), from the Department of Haematology, Shandong Provin- cial Hospital Affiliated to Shandong University, were included in this study from January 2013 to July 2016. The study was approved by the Medical Ethics Committee of the hospital, and informed consent documents were obtained from each patient in accordance with the Declaration of Helsinki. Clinical information was carefully obtained, including baseline demographics, peripheral blood cell counts, bone marrow (BM) blast counts, diagnosis, therapy, leukaemic transformation, the date of the last contact with the patient, and the patient's status at the last follow-up. We calculated the overall survival (OS) of patients with MDS using the date of diagnosis and the date of the last contact with the patient or their death. For patients with MDS, progression-free survival (PFS) was calculated from the date of diagnosis to the date of leukaemia transformation, death, or the last contact with the patient without disease progression. The International Prognostic Scoring System (IPSS) risk classification system was applied to make therapeutic decisions. Decitabine treatment was recommended for patients in the intermediate- and high-risk groups, but only 31 patients consented. The others accepted supportive treatment, with the exception of 4 who underwent chemotherapy. The low-risk patients received conservative and supportive care. Only 5 patients received allo-transplantation.

\section{IDH Mutation Analysis}

DNA was extracted from samples from the MDS patients using the TIANamp blood DNA kit (TIANGEN, Beijing, China) following the manufacturer's instructions. Exon 4 of the IDH1 and $I D H 2$ genes was amplified from each patient's DNA using a polymerase chain reaction (PCR) assay, and sequenced for somatic mutations. The PCR assay to detect $I D H 1$ exon 4 mutations was conducted using the following primer sequences: sense $5^{\prime}$-CGGTCTTCAGAGAAGCCATT- $3^{\prime}$ and anti-sense $5^{\prime}$-CACATTATTGCCAACATGAC-3' [14]. IDH2 exon 4 was done using sense $5^{\prime}$-CCACTATTATCTCTGTCCTC- $3^{\prime}$ and anti-sense 5'-GCTAGGCGAGGAGCTCCAGT-3' [25]. PCR was performed in a $50-\mu \mathrm{L}$ volume, containing $25 \mu \mathrm{L}$ of PrimeSTAR Max Premix $(2 \times)$ (Takara, Dalian, China), $1 \mu \mathrm{L}$ (100 ng) of DNA, $1 \mu \mathrm{L}(10 \mu \mathrm{M})$ of each of the sense and anti-sense primers, and $22 \mu \mathrm{L}$ of $\mathrm{dH}_{2} \mathrm{O}$. The thermal cycling programme was as follows: $3 \mathrm{~min}$ at $94^{\circ} \mathrm{C}$, followed by 35 cycles of denaturing at $94^{\circ} \mathrm{C}$ for $15 \mathrm{~s}$, annealing at $57^{\circ} \mathrm{C}$ for $5 \mathrm{~s}$, and extension at $72^{\circ} \mathrm{C}$ for $40 \mathrm{~s}$. The resulting PCR products were sent to a sequencing company (BioSune Biotechnology Co., Ltd., Shanghai, China) for purification and the detection of $I D H 1$ and $I D H 2$ gene mutations via direct DNA sequencing techniques. Abnormal sequencing results were confirmed through at least 2 repeated analyses.

\section{Cytogenetic Analysis}

Bone marrow cells were collected at the time of the diagnosis of MDS, and metaphase chromosomes were identified according to the guidelines of the International Society for Cytogenetic Nomenclature (ISCN) [26]. According to the ISCN, at least 20 metaphase cells must be analysed and at least 2 metaphases must exhibit the same aberration in terms of a structural abnormality or extra chromosome. Karyotype risk stratification was defined as follows: good, normal karyotype, isolated $-\mathrm{Y}$, del (5q) or del (20q-); poor, complex ( $\geq 3$ abnormalities) or chromosome 7 anomalies; intermediate, other abnormalities.
144

Acta Haematol 2017;138:143-151

DOI: $10.1159 / 000479546$
Wang/Wang/Shan/Sui/Xu 
Table 1. Comparison of clinical data from 97 cases of MDS patients with mutated or wild-type IDH

\begin{tabular}{|c|c|c|c|c|}
\hline Variable & IDH1 mutation $(n=3)$ & IDH 2 mutation $(n=4)$ & Wild type $(n=90)$ & $p$ value \\
\hline Age, years & $51(49-60)$ & $64(60-66)$ & $59(13-80)$ & 0.694 \\
\hline Male/female & $2 / 1$ & $2 / 2$ & $56 / 34$ & 0.543 \\
\hline $\mathrm{Hb}, \mathrm{g} / \mathrm{L}$ & $62(42-76)$ & $91(56-112)$ & $66(27-132)$ & 0.549 \\
\hline WBC, $\times 10^{9} / \mathrm{L}$ & $1.68(1.31-1.68)$ & $1.69(1.54-9.97)$ & $2.66(0.70-32.60)$ & 0.064 \\
\hline $\mathrm{ANC}, \times 10^{9} / \mathrm{L}$ & $0.46(0.20-0.51)$ & $0.43(0.19-4.50)$ & $1.21(0.00-24.00)$ & $0.027^{*}$ \\
\hline Platelets, $\times 10^{9} / \mathrm{L}$ & $12(10-25)$ & $45(23-80)$ & $45(4-827)$ & 0.130 \\
\hline BM blasts, \% & $6.0(5.0-10.0)$ & $12.0(10.0-16.0)$ & $2.3(0-19.0)$ & $0.019^{*}$ \\
\hline Karyotype risk ${ }^{\mathrm{a}}$ & & & & 0.786 \\
\hline Good & 3 & 0 & 49 & \\
\hline Intermediate & 0 & 2 & 24 & \\
\hline Poor & 0 & 2 & 17 & \\
\hline 2008 WHO classification & & & & 0.077 \\
\hline RCUD & 0 & 0 & 3 & \\
\hline RARS & 0 & 0 & 9 & \\
\hline RCMD & 0 & 0 & 39 & \\
\hline RAEB-1 & 2 & 0 & 10 & \\
\hline RAEB-2 & 1 & 4 & 29 & \\
\hline IPSS-R risk category ${ }^{\mathrm{b}}$ & & & & 0.111 \\
\hline Very low & 0 & 0 & 0 & \\
\hline Low & 0 & 0 & 17 & \\
\hline Intermediate & 0 & 0 & 26 & \\
\hline High & 3 & 1 & 26 & \\
\hline Very high & 0 & 3 & 21 & \\
\hline \multicolumn{5}{|l|}{ IPSS risk category ${ }^{\mathrm{c}}$} \\
\hline Low & 0 & 0 & 4 & 0.119 \\
\hline Int-1 & 3 & 0 & 51 & \\
\hline Int-2 & 0 & 1 & 25 & \\
\hline High & 0 & 3 & 10 & \\
\hline Death & 3 & 2 & 34 & 0.113 \\
\hline Leukaemic transformation & 1 & 0 & 17 & 0.615 \\
\hline
\end{tabular}

Values are expressed as $n$ or median (range). ANC, absolute neutrophil count; BM, bone marrow; IDH, isocitrate dehydrogenase; Int, intermediate; IPSS, International Prognostic Scoring System; IPSS-R, revised IPSS; RAEB, refractory anaemia with excess blasts; RARS, refractory anaemia with ring sideroblasts; RCMD, refractory anaemia with multilineage dysplasia; RCUD, refractory cytopenia with unilineage dysplasia; WBC, white blood cell count; WHO, World Health Organization. * Significant difference. ${ }^{a}$ Good, normal karyotype, isolated-Y, del (5q) or del (20q); poor, complex ( $\geq 3$ abnormalities) or chromosome 7 anomalies; intermediate, other abnormalities. ${ }^{\mathrm{b}}$ Very low, 1.5 ; low, $>1.5-3$; intermediate, $>3-4.5$; high, $>4.5-6$; and very high, $>6 .{ }^{\mathrm{c}}$ Low, 0 ; Int $-1,0.5-1.0$; Int-2, $1.5-2.0$; high, $\geq 2.5$.

\section{Statistical Analysis}

Statistical analysis was performed with SPSS v17.0 (SPSS, Chicago, IL, USA). The differences between patients according to their IDH 1 and IDH 2 mutational status were tested using the Pearson $\chi^{2}$ test or the Fisher exact test for categorical variables. Differences in continuous variables were compared with the Mann-Whitney $\mathrm{U}$ test for 2 groups. Kaplan-Meier survival curves were plotted for the estimated probabilities of disease-free survival and OS, and the survival distributions were compared using the log-rank test. The Cox proportional-hazards regression model was applied for multivariate analysis to analyse independent prognostic factors for OS and PFS. The reported $p$ values are 2 -sided, and $p<0.05$ was considered to indicate statistical significance.

\section{Results}

\section{Frequency and Type of IDH Mutation}

We detected 7 IDH mutations in the total cohort of 97 patients (7.2\%). Sequence analysis of IDH1 mutations in the 97 samples revealed 3 somatic mutations (3.1\%, 3/97), all at residue $\mathrm{R} 132 \mathrm{C}$ (Arg132Cys). Sequencing evaluation of $\mathrm{IDH} 2$ mutations revealed 4 somatic mutations in $\mathrm{IDH} 2$ (4.1\%, 4/97), including R140Q (Arg140Gln) in 3 patients and R140L (Arg140Leu) in the other patient. All of the patients carrying the missense mutation were heterozy-

Acta Haematol 2017;138:143-151 
Table 2. Details of $6 I D H 1 / 2$ mutations in patients with MDS

\begin{tabular}{|c|c|c|c|c|c|c|}
\hline $\begin{array}{l}\text { Patient } \\
\text { No. }\end{array}$ & $\begin{array}{l}\text { Age, } \\
\text { years }\end{array}$ & Sex & Gene & $\begin{array}{l}\text { WHO classification } \\
(2008)\end{array}$ & Karyotype & $\begin{array}{l}\text { Survival status at } \\
\text { different time points }\end{array}$ \\
\hline 001 & 49 & male & IDH1 R132C & RAEB-1 & $46, \mathrm{XY}[20]$ & 11 months: dead \\
\hline 002 & 51 & male & IDH1 R132C & RAEB-2 & $46, \mathrm{XY}[20]$ & 7 months: dead \\
\hline 003 & 60 & female & IDH1 R132C & RAEB-1 & $46, \mathrm{XX}[20]$ & 12 months: dead \\
\hline 004 & 62 & female & IDH2 R140Q & RAEB-2 & $47, \mathrm{XX},+8[20]$ & 18 months: alive \\
\hline 005 & 66 & male & IDH2 R140Q & RAEB-2 & $47, \mathrm{XY},+8[20]$ & 16 months: alive \\
\hline 006 & 60 & female & IDH2 R140Q & RAEB-2 & $\begin{array}{l}41-45, X X, \operatorname{add}(2)(\mathrm{p} 25) \\
-5, \operatorname{del}(7)(\mathrm{q} 31), \operatorname{add}(12) \\
(\mathrm{p} 13), \operatorname{rob}(14 ; 15) \\
(\mathrm{q} 10 ; \mathrm{q} 10),-16,+22,+ \text { mar, } \\
\text { inc }[\mathrm{CP} 18] / 46, \mathrm{XX}[2]\end{array}$ & 3 months: dead \\
\hline 007 & 66 & male & IDH2 R140L & RAEB-2 & $\begin{array}{l}45, \mathrm{XY}, \operatorname{add}(9)(\mathrm{p} 24),-14, \\
-17,-17,-20,-20,-22, \\
+6 \text { mar,Inc }[\mathrm{CP} 18] / 46, \mathrm{XY}[2]\end{array}$ & 5 months: dead \\
\hline
\end{tabular}

gous and mutually exclusive. All of the $I D H$ mutations occurred in patients with refractory anaemia with excess blasts (RAEB). The frequency of IDH1 mutations was $16.7 \%(2 / 12)$ in the RAEB-1 patient cohort, while the frequency of $I D H 2$ mutations was 0 . Additionally, among the RAEB-2 patients, $2.9 \%(1 / 34)$ of the patients exhibited an $I D H 1$ mutation, and $11.8 \%$ of patients exhibited $I D H 2$ mutations $(4 / 34)$.

\section{Patients' Clinical Features in Relation to IDH \\ Mutations}

The characteristics of the 60 male and 37 female MDS patients are summarized in Table 1 according to their IDH1/2 mutation status. The patients' ages ranged from 13 to 80 years, with a median of 59 years. Among the 97 patients, $39(40.2 \%)$ had died by the last follow-up, and 18 patients (18.6\%) had developed AML. Patients with IDH mutations presented higher BM blast counts (median 10.0 vs. $2.3 \% ; p=0.019$ ), lower absolute neutrophil counts (median $0.44 \times 10^{9} / \mathrm{L}$ vs. $1.21 \times 10^{9} / \mathrm{L} ; p=0.027$ ) and a higher ratio of decitabine treatment ( 21.4 vs. $28.9 \%$; $p=0.032$ ). There was no significant difference in other clinical parameters, including age, sex, haemoglobin, platelets, karyotype risk, transplantation rate, $2008 \mathrm{WHO}$ classification, or IPSS [27] or revised IPSS (IPSS-R) risk stratification [3] between the patients with $I D H$ mutations and those without such mutations. Patients with IDH1 mutations presented lower white blood cell counts (median $1.68 \times 10^{9} / \mathrm{L}$ vs. $2.66 \times 10^{9} / \mathrm{L} ; p=0.048$ ) and lower absolute neutrophil counts (median $0.46 \times 10^{9} / \mathrm{L}$ vs. $1.21 \times 10^{9} / \mathrm{L} ; p=0.016$ ). Patients with $I D H 2$ mutations presented higher BM blast counts (median 12.0 vs. 2.3\%; $p=0.013$ ) and lower absolute neutrophil counts (median $0.43 \times 10^{9} / \mathrm{L}$ vs. $\left.1.21 \times 10^{9} / \mathrm{L} ; p=0.016\right)$ and IPSS risk stratification $(p=0.044)$. Notably, among the 18 patients showing leukaemic transformation, only 1 exhibited an IDH1 mutation and all (100\%) of the patients showing leukaemic transformation had died by the last follow-up. Additionally, 5 (71.43\%) patients with IDH mutations had died, including 3 with IDH1 mutations and 2 with IDH 2 mutations. Forty-seven of the 51 non-RAEB MDS patients received conservative and supportive care and the other 4 received decitabine treatment. Of the 46 MDS-RAEB patients included in this study, 27 were treated with decitabine, 4 underwent chemotherapy, and the others received supportive treatment for various reasons.

\section{Correlation of IDH Mutations with Cytogenetics}

All chromosomal information was obtained from the 97 patients at diagnosis, and clonal chromosomal abnormalities were detected in 51 patients (52.6\%). The frequency of $I D H$ mutations associated with abnormal karyotypes $(4 / 51,7.8 \%)$ was similar to the frequency associated with normal karyotypes $(3 / 46,6.5 \%)$, with no statistically significant difference $(p=0.802)$. There was no significant association of $I D H$ mutations with any special karyotype. Notably, the karyotypes of the chromosomes of the patients carrying IDH1 mutations were all normal. However, there was no significant difference in karyotype between IDH1 or IDH2 mutations and the wild type. Among the 4 patients with $I D H 2$ mutations, 2 patients exhibited trisomy 8 , and 2 displayed complex chromosome abnormalities, 1 of which included the chromo-
146

Acta Haematol 2017;138:143-151 DOI: $10.1159 / 000479546$
Wang/Wang/Shan/Sui/Xu 


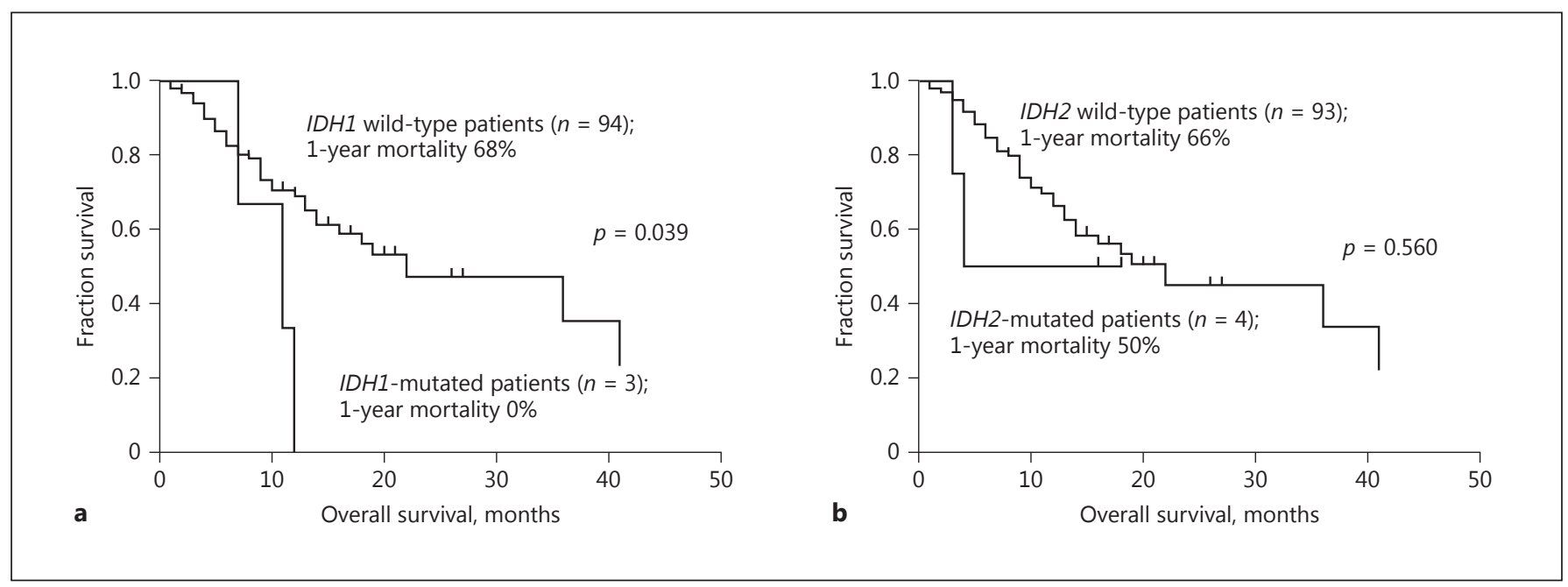

Fig. 1. a Overall survival in MDS patients with mutated and wild-type IDH1 (log-rank test; $p=0.039$ ). b Overall survival in MDS patients with mutated and wild-type IDH2 (log-rank test; $p=0.560)$. Kaplan-Meier curves.
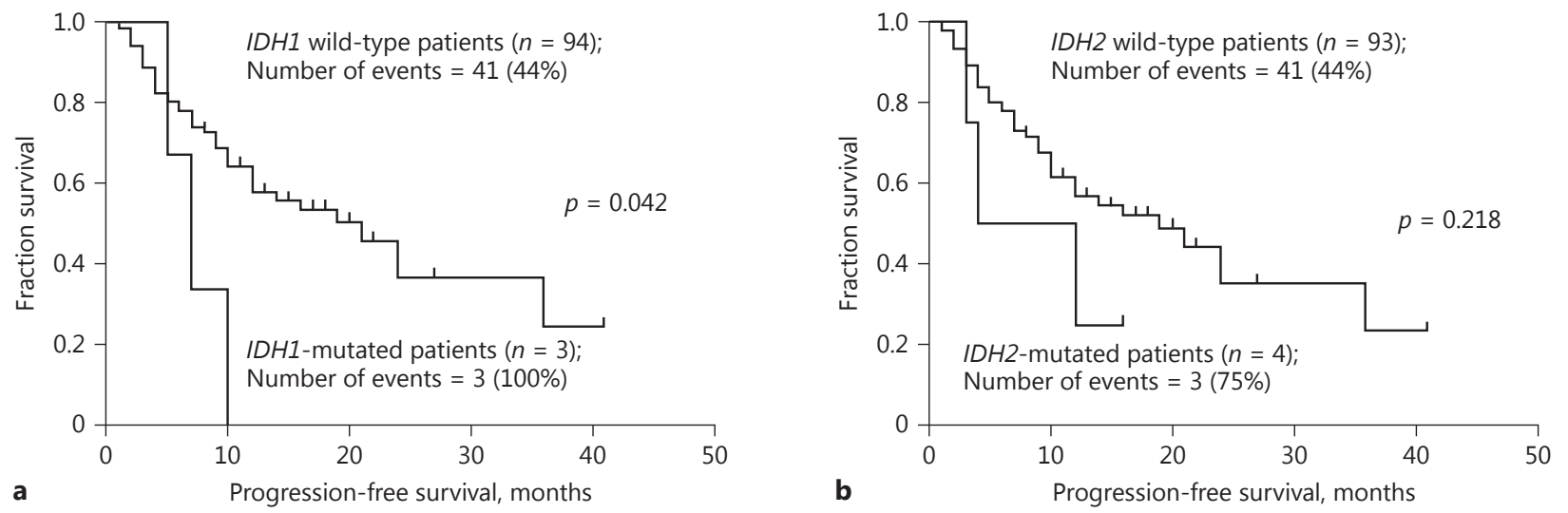

Fig. 2. a Progression-free survival in MDS patients with mutated and wild-type IDH1 (log-rank test; $p=0.042)$. b Progression-free survival in MDS patients with mutated and wild-type IDH2 (log-rank test; $p=0.218$ ). KaplanMeier curves.

some 17 deletion $(-17)$ and the chromosome 20 deletion (-20) (Table 2).

\section{Prognostic Impact of IDH1 and IDH2 Mutations}

For the assessment of the influence of IDH1 and IDH2 mutations on the prognosis, follow-up data were available for all 97 MDS patients. The median follow-up duration was 10.0 months (range 1.0-41.0 months). The median OS was 19.8 months, while the median PFS was 16.9 months. Patients with IDH1 mutations exhibited shorter OS than those without such mutations (median 11.5 vs.
22.3 months; $p=0.039$; Fig. 1a), and the 1-year survival rates were 0 and $68 \%$ for patients with $m I D H 1$ and the wild type, respectively. Patients harbouring IDH2 mutations showed no difference in OS compared with those without IDH2 mutations (median 18.0 vs. 19.7 months; $p=0.560$; Fig. $1 \mathrm{~b}$ ), and the 1-year survival rates were 50 and $66 \%$ for patients with $m I D H 2$ and the wild-type, respectively.

The presence of $I D H 1$ mutations in patients predicted reduced PFS when compared with the absence of $I D H 1$ mutations (median 7.5 vs. 19.6 months; $p=0.042$; Fig. 2a). 
Table 3. Cox regression analysis for overall survival in MDS patients with mutated or wild-type $I D H$

\begin{tabular}{lll}
\hline Variables & $\begin{array}{l}\text { Univariate } \\
\text { analysis, } \\
p \text { value }\end{array}$ & $\begin{array}{l}\text { Multivariate } \\
\text { analysis, } \\
p \text { value }\end{array}$ \\
\hline 2008 WHO classification & $<0.0001^{*}$ & 0.178 \\
IPSS-R risk categories & $<0.0001^{*}$ & $<0.0001^{*}$ \\
Karyotype risk & $<0.0001^{*}$ & $0.036^{*}$ \\
IDH1 mutation & $0.039^{*}$ & $0.018^{*}$ \\
IDH2 mutation & 0.560 & 0.615 \\
\hline
\end{tabular}

$\mathrm{IDH}$, isocitrate dehydrogenase; IPSS-R, revised International Prognostic Scoring System; WHO, World Health Organization. * Significant difference.

Patients with IDH2 mutations exhibited no difference in PFS when compared with those without IDH2 mutations (median 12.0 vs. 19.4 months; $p=0.218$; Fig. $2 b$ ).

Multivariate analysis demonstrated that $\mathrm{IDH} 1$ mutation ( $p=0.018$; hazard ratio [HR] 4.735; 95\% confidence interval [CI] 1.299-17.264), karyotype risk ( $p=0.036$; HR 1.619; 95\% CI 1.033-2.539), and IPSS-R risk category $(p<0.0001$; HR 2.122; 95\% CI 1.401-3.213) were independent inferior prognostic factors for OS (Table 3 ).

\section{Discussion}

In this study, the incidence of mutations of IDH identified in MDS patients from northern China was $7.2 \%$ (3.1\% IDH1 mutations and $4.1 \%$ IDH2 mutations). Thus far, there have been few studies concerning $I D H$ mutations in Asian MDS patients. The frequency of IDH mutations found in this study was similar to that identified in 2 previously published studies with southern Chinese MDS patients and 1 small study of 22 MDS patients in Thailand [22, 23, 28]. However, Lin et al. [24] reported that the rate of $I D H$ mutations in Taiwanese patients with MDS may be as low as $4.6 \%$ (22/477). Some studies have shown that the mutation rate of $I D H$ in Caucasian MDS patients is between 4 and 12\% [29]. In a study from the Mayo Clinic, it was shown that MDS patients with refractory cytopenia with multilineage dysplasia or RAEB exhibited higher $I D H$ mutation rates than those with refractory anaemia [21]. We found that the MDS patients with relatively higher risk (the RAEB patients) exhibited a higher $I D H$ mutation rate, as observed in Caucasian patients. The frequency of IDH1 and IDH2 mutations was much higher in patients with AML than in MDS patients. One review indicated that $I D H$ mutations are among the most common mutations found in AML patients, with IDH1 mutations occurring in $7-14 \%$ and IDH2 mutations in $8-19 \%$ [30]. Our research also showed that $I D H$ mutations are closely associated with higher BM blast counts and lower absolute neutrophil counts. All of the above findings suggest that $I D H$ mutations may be associated with the progression of MDS.

In accordance with our findings, all previous studies have determined that the frequency of IDH1 mutations is lower than that of IDH2 mutations in MDS. The reasons for the variation in $m I D H$ frequency in different studies are related to the limitations in sequencing technology, selection bias, and ethnic and geographical differences. Our study showed that all of the identified mutations were mutually exclusive. Notably, a recent study identified dual mutations in the IDH1 and IDH2 genes in MDS via targeted next-generation sequencing [31].

Some recent publications have shown that normal karyotypes in patients harbouring IDH mutations indicate adverse outcomes in AML [32]. Nevertheless, no significant relationship between $I D H$ mutations and any special karyotype was observed in our study, suggesting that $I D H$ mutations may influence MDS via mechanisms different from those in AML. In addition, 1 study showed that the frequency of $I D H$ mutations in patients with trisomy-8-associated MDS and AML was much higher than in those with MDS or AML without isolated trisomy 8, although in patients with trisomy-8-associated MDS, the prognosis was not significantly different between those with and those without $I D H$ mutations [33]. In this study, we identified $3 \mathrm{mIDH}$ patients who exhibited karyotype abnormalities typical of MDS, such as $+8,-17$, and $20 \mathrm{q}-$. Thus, we have reason to believe that $I D H 2$ mutations are related to the pathogenesis and progression of MDS. Due to the limited number of cases examined and the low frequency of typical MDS karyotypes, we did not statistically calculate the effect of $I D H 2$ mutations in these abnormal karyotypes on the prognosis of MDS. Additional investigations are needed to infer the relationship between IDH mutations and typical karyotypes of MDS.

Two meta-analyses have shown that patients with mIDH1 CN-AML exhibit lower rates of complete remission and inferior OS when compared with those without IDH 1 mutations [34, 35]. Another meta-analysis revealed that the $I D H 1$ mutation may be associated with inferior event-free survival, while the IDH2 mutation was observed to improve OS [36]. However, the prognostic impact of IDH1 and IDH2 mutations in MDS has always
148

Acta Haematol 2017;138:143-151 DOI: $10.1159 / 000479546$
Wang/Wang/Shan/Sui/Xu 
been controversial. Some studies suggest that IDH1 mutations in patients with MDS are associated with an unfavourable prognosis $[11,21,23]$. Conversely, 2 other studies showed that IDH2 mutations, rather than IDH1 mutations, were associated with significantly shorter OS in an MDS cohort $[9,24]$. A few studies have also found no influence of $I D H$ mutations on OS in MDS patients [10, $22,37]$. In our MDS cohort, we observed that IDH1 mutations were associated with shorter OS and PFS, whereas IDH2 mutations had no impact. Interestingly, 1 study showed that IDH1 R132 mutations could increase hypoxia-inducible factor $1 \alpha$ (HIF-1 $\alpha$ ) levels, which promotes tumour growth when oxygen levels decrease, and the stability of HIF-1a is regulated by $\alpha-K G$ [38]. Moreover, in 2 other studies, it was shown that DNA hypermethylation and HIF-1 $\alpha$ expression predict a poor prognosis in MDS $[39,40]$. Notably, biochemical studies have demonstrated that the capacity of different IDH mutations differs. The most effective $I D H$ mutation is $I D H 2 \mathrm{R} 172 \mathrm{~K}$, followed by IDH1 R132H, IDH1 R132C, and IDH2 R140Q [41]. In our study, 3 IDH1 R132C mutations, 3 IDH2 R140Q mutations, and 1 R140L mutation were identified. Thus, the inhibition ability of $\alpha-K G$-dependent enzymes is significantly different among different IDH1/2 mutations, which may partially explain the difference in prognosis of MDS between $I D H 1$ mutations and $I D H 2$ mutations. The occurrence of the IDH2 R140L mutation is rare, and the associated OS has not been reported in the literature. The OS of the patient in our cohort harbouring an IDH2 R140L mutation was only 5 months. This patient also exhibited lower IDH2 expression than the patients with the IDH2 R140Q mutation, according to real-time fluorescence quantitative PCR analysis. This finding may indicate that the IDH2 R140L mutation exhibits a stronger a-KG-dependent enzyme-suppressing ability than the IDH2 R140Q mutation; however, due to our limited data, we could not statistically confirm this result.

In addition, $I D H 1$ mutations, rather than $I D H 2$ mutations, represent an adverse prognostic factor in MDS, which may be due to the close association of $I D H 1$ mutations with DNMT3A and NPM1 mutations, while IDH2 mutations are closely associated with SRSF2, ASXL1, STAG2, and RUNX1 mutations [42]. A series of IDHmutated inhibitors are currently under study, including first-generation inhibitors of IDH1 (AG120, IDH-305, and FT-2102) and IDH2 (AG221) mutants, and a secondgeneration pan-inhibitor (AG881). Both the IDH1 inhibitors (AG120 and FT305) and the IDH2 inhibitor (enasidenib) have shown promising effects in relapsed and refractory AML patients $[43,44]$. We believe that IDH1- mutant inhibitors will be widely applied in the clinical therapy of MDS as a promising therapeutic option in the future.

In conclusion, the incidence of IDH mutations in northern Chinese MDS patients is 7.2\%. IDH mutations were closely associated with higher BM blast counts and lower absolute neutrophil counts, and showed no relationship with any specific karyotype. IDH1 mutation, karyotype risk, and IPSS-R risk category were found to be independent inferior prognostic factors for MDS. Due to the limited sample size, the results of our study should be treated cautiously, and the adverse prognostic impact of IDH1 mutations should be validated by large samples. We believe that if a larger study is conducted, it will be demonstrated that IDH1 mutations can serve as a useful biomarker for the timely and proper treatment of MDS.

\section{Acknowledgements}

This work was supported by grants from the Natural Science Foundation of Shandong Province (No. ZR2015PH028), the National Science Foundation of China (No. 81570104), the Medicine and Health Science Technology Development Project in Shandong Province (No. 2014WS0348), and the Key Research and Development Project of Shandong Province (No. 2015GSF118058).

\section{Disclosure Statement}

The authors declare that they have no competing interests.

\section{References}

1 Vardiman JW, Harris NL, Brunning RD: The World Health Organization (WHO) classification of the myeloid neoplasms. Blood 2002; 100:2292-2302

2 Vardiman JW, Thiele J, Arber DA, Brunning $\mathrm{RD}$, Borowitz MJ, Porwit A, Harris NL, Le Beau MM, Hellström-Lindberg E, Tefferi A, Bloomfield CD: The 2008 revision of the World Health Organization (WHO) classification of myeloid neoplasms and acute leukemia: rationale and important changes. Blood 2009;114:937-951.

3 Greenberg PL, Tuechler H, Schanz J, Sanz G, Garcia-Manero G, Solé F, Bennett JM, Bowen D, Fenaux P, Dreyfus F, Kantarjian H, Kuendgen A, Levis A, Malcovati L, Cazzola M, Cermak J, Fonatsch C, Le Beau MM, Slovak ML, Krieger O, Luebbert M, Maciejewski J, Magalhaes SM, Miyazaki Y, Pfeilstöcker M, Sekeres M, Sperr WR, Stauder R, Tauro S, Valent $\mathrm{P}$, Vallespi T, van de Loosdrecht AA, Germing U, Haase D: Revised international prognostic scoring system for myelodysplastic syndromes. Blood 2012;120:2454-2465.

IDH1 in MDS 
4 Aul C, Bowen DT, Yoshida Y: Pathogenesis, etiology and epidemiology of myelodysplastic syndromes. Haematologica 1998;83:71-86.

5 Kosmider O, Gelsi-Boyer V, Cheok M, Grabar S, Della-Valle V, Picard F, Viguié F, Quesnel B, Beyne-Rauzy O, Solary E, Vey N, HunaultBerger M, Fenaux P, Mansat-De Mas V, Delabesse E, Guardiola P, Lacombe C, Vainchenker W, Preudhomme C, Dreyfus F, Bernard OA, Birnbaum D, Fontenay M: TET2 mutation is an independent favorable prognostic factor in myelodysplastic syndromes (MDSs). Blood 2009;114:3285-3291.

6 Patnaik MM, Lasho TL, Hodnefield JM, Knudson RA, Ketterling RP, Garcia-Manero G, Steensma DP, Pardanani A, Hanson CA, Tefferi A: SF3B1 mutations are prevalent in myelodysplastic syndromes with ring sideroblasts but do not hold independent prognostic value. Blood 2012;119:569-572.

7 Walter MJ, Ding L, Shen D, Shao J, Grillot M, McLellan M, Fulton R, Schmidt H, KalickiVeizer J, O'Laughlin M, Kandoth C, Baty J, Westervelt P, DiPersio JF, Mardis ER, Wilson RK, Ley TJ, Graubert TA: Recurrent DNMT3A mutations in patients with myelodysplastic syndromes. Leukemia 2011;25:1153-1158.

8 Yoshida K, Sanada M, Shiraishi Y, Nowak D, Nagata Y, Yamamoto R, Sato Y, Sato-Otsubo A, Kon A, Nagasaki M, Chalkidis G, Suzuki Y, Shiosaka M, Kawahata R, Yamaguchi T, Otsu M, Obara N, Sakata-Yanagimoto M, Ishiyama K, Mori H, Nolte F, Hofmann WK, Miyawaki S, Sugano S, Haferlach C, Koeffler HP, Shih LY, Haferlach T, Chiba S, Nakauchi H, Miyano $S$, Ogawa $S$ : Frequent pathway mutations of splicing machinery in myelodysplasia. Nature 2011;478:64-69.

9 Bejar R, Stevenson K, Abdel-Wahab O, Galili N, Nilsson B, Garcia-Manero G, Kantarjian H, Raza A, Levine RL, Neuberg D, Ebert BL: Clinical effect of point mutations in myelodysplastic syndromes. N Engl J Med 2011;364: 2496-2506.

10 Kosmider O, Gelsi-Boyer V, Slama L, Dreyfus F, Beyne-Rauzy O, Quesnel B, Hunault-Berger M, Slama B, Vey N, Lacombe C, Solary E, Birnbaum D, Bernard OA, Fontenay M: Mutations of $I D H 1$ and $I D H 2$ genes in early and accelerated phases of myelodysplastic syndromes and MDS/myeloproliferative neoplasms. Leukemia 2010;24:1094-1096.

11 Thol F, Weissinger EM, Krauter J, Wagner K, Damm F, Wichmann M, Göhring G, Schumann C, Bug G, Ottmann O, Hofmann WK, Schlegelberger B, Ganser A, Heuser M: IDH1 mutations in patients with myelodysplastic syndromes are associated with an unfavorable prognosis. Haematologica 2010;95:16681674.

12 Mardis ER, Ding L, Dooling DJ, Larson DE, McLellan MD, Chen K, Koboldt DC, Fulton RS, Delehaunty KD, McGrath SD, Fulton LA, Locke DP, Magrini VJ, Abbott RM, Vickery TL, Reed JS, Robinson JS, Wylie T, Smith SM, Carmichael L, Eldred JM, Harris CC, Walker J, Peck JB, Du F, Dukes AF, Sanderson GE,
Brummett AM, Clark E, McMichael JF, Meyer RJ, Schindler JK, Pohl CS, Wallis JW, Shi X, Lin L, Schmidt H, Tang Y, Haipek C, Wiechert ME, Ivy JV, Kalicki J, Elliott G, Ries RE, Payton JE, Westervelt P, Tomasson MH, Watson MA, Baty J, Heath S, Shannon WD, Nagarajan R, Link DC, Walter MJ, Graubert TA, DiPersio JF, Wilson RK, Ley TJ: Recurring mutations found by sequencing an acute myeloid leukemia genome. N Engl J Med 2009;361: 1058-1066.

13 Boissel N, Nibourel O, Renneville A, Gardin C, Reman O, Contentin N, Bordessoule D, Pautas C, de Revel T, Quesnel B, Huchette P, Philippe N, Geffroy S, Terre C, Thomas X, Castaigne S, Dombret $\mathrm{H}$, Preudhomme C: Prognostic impact of isocitrate dehydrogenase enzyme isoforms 1 and 2 mutations in acute myeloid leukemia: a study by the Acute Leukemia French Association group. J Clin Oncol 2010;28:3717-3723.

14 Green CL, Evans CM, Zhao L, Hills RK, Burnett AK, Linch DC, Gale RE: The prognostic significance of IDH2 mutations in AML depends on the location of the mutation. Blood 2011;118:409-412.

15 Abbas S, Lugthart S, Kavelaars FG, Schelen A, Koenders JE, Zeilemaker A, van Putten WJ, Rijneveld AW, Löwenberg B, Valk PJ: Acquired mutations in the genes encoding IDH1 and IDH2 both are recurrent aberrations in acute myeloid leukemia: prevalence and prognostic value. Blood 2010;116:2122-2126.

16 Tefferi A, Lasho TL, Abdel-Wahab O, Guglielmelli P, Patel J, Caramazza D, Pieri L, Finke CM, Kilpivaara O, Wadleigh M, Mai M, McClure RF, Gilliland DG, Levine RL, Pardanani A, Vannucchi AM: IDH1 and IDH2 mutation studies in 1,473 patients with chronic-, fibrotic- or blast-phase essential thrombocythemia, polycythemia vera or myelofibrosis. Leukemia 2010;24:1302-1309.

17 Clark O, Yen K, Mellinghoff IK: Molecular Pathways: isocitrate dehydrogenase mutations in cancer. Clin Cancer Res 2016;22: 1837-1842.

18 Krell D, Mulholland P, Frampton AE, Krell J, Stebbing J, Bardella C: IDH mutations in tumorigenesis and their potential role as novel therapeutic targets. Future Oncol 2013;9: 1923-1935.

19 Dang L, White DW, Gross S, Bennett BD, Bittinger MA, Driggers EM, Fantin VR, Jang HG, Jin S, Keenan MC, Marks KM, Prins RM, Ward PS, Yen KE, Liau LM, Rabinowitz JD, Cantley LC, Thompson CB, Vander Heiden MG, Su SM: Cancer-associated IDH1 mutations produce 2-hydroxyglutarate. Nature 2009;462:739-744.

20 Figueroa ME, Abdel-Wahab O, Lu C, Ward PS, Patel J, Shih A, Li Y, Bhagwat N, Vasanthakumar A, Fernandez HF, Tallman MS, Sun Z, Wolniak K, Peeters JK, Liu W, Choe SE, Fantin VR, Paietta E, Löwenberg B, Licht JD, Godley LA, Delwel R, Valk PJ, Thompson CB, Levine RL, Melnick A: Leukemic IDH1 and IDH2 mutations result in a hypermethylation phenotype, disrupt TET2 function, and impair hematopoietic differentiation. Cancer Cell 2010;18:553-567.

21 Patnaik MM, Hanson CA, Hodnefield JM, Lasho TL, Finke CM, Knudson RA, Ketterling RP, Pardanani A, Tefferi A: Differential prognostic effect of $I D H 1$ versus $I D H 2$ mutations in myelodysplastic syndromes: a Mayo Clinic study of 277 patients. Leukemia 2012;26:101105.

22 Lin J, Yao DM, Qian J, Chen Q, Qian W, Li Y, Yang J, Wang CZ, Chai HY, Qian Z, Xiao GF, Xu WR: IDH1 and IDH2 mutation analysis in Chinese patients with acute myeloid leukemia and myelodysplastic syndrome. Ann Hematol 2012;91:519-525.

23 Jin J, Hu C, Yu M, Chen F, Ye L, Yin X, Zhuang $\mathrm{Z}$, Tong $\mathrm{H}$ : Prognostic value of isocitrate dehydrogenase mutations in myelodysplastic syndromes: a retrospective cohort study and meta-analysis. PLoS One 2014;9:e100206.

24 Lin CC, Hou HA, Chou WC, Kuo YY, Liu CY, Chen CY, Lai YJ, Tseng MH, Huang CF, Chiang YC, Lee FY, Liu MC, Liu CW, Tang JL, Yao M, Huang SY, Ko BS, Wu SJ, Tsay W, Chen YC, Tien HF: IDH mutations are closely associated with mutations of DNMT3A, ASXL1 and SRSF2 in patients with myelodysplastic syndromes and are stable during disease evolution. Am J Hematol 2014;89:137-144.

25 Tefferi A, Jimma T, Sulai NH, Lasho TL, Finke CM, Knudson RA, McClure RF, Pardanani A: $I D H$ mutations in primary myelofibrosis predict leukemic transformation and shortened survival: clinical evidence for leukemogenic collaboration with JAK2V617F. Leukemia 2012;26:475-480.

26 Simons A, Shaffer LG, Hastings RJ: Cytogenetic Nomenclature: changes in the ISCN 2013 compared to the 2009 edition. Cytogenet Genome Res 2013;141:1-6.

27 Greenberg P, Cox C, LeBeau MM, Fenaux P, Morel P, Sanz G, Sanz M, Vallespi T, Hamblin T, Oscier D, Ohyashiki K, Toyama K, Aul C, Mufti G, Bennett J: International scoring system for evaluating prognosis in myelodysplastic syndromes. Blood 1997;89:2079-2088.

28 Chotirat S, Thongnoppakhun W, Wanachiwanawin W, Auewarakul CU: Acquired somatic mutations of isocitrate dehydrogenases 1 and 2 (IDH1 and IDH2) in preleukemic disorders. Blood Cells Mol Dis 2015;54:286-291.

29 Ganguly BB, Kadam NN: Mutations of myelodysplastic syndromes (MDS): an update. Mutat Res Rev Mutat Res 2016;769:47-62.

30 Medeiros BC, Fathi AT, DiNardo CD, Pollyea DA, Chan SM, Swords R: Isocitrate dehydrogenase mutations in myeloid malignancies. Leukemia 2017;31:272-281.

31 Platt MY, Fathi AT, Borger DR, Brunner AM, Hasserjian RP, Balaj L, Lum A, Yip S, DiasSantagata D, Zheng Z, Le LP, Graubert TA, Iafrate AJ, Nardi V: Detection of dual IDH1 and $\mathrm{IDH} 2$ mutations by targeted next-generation sequencing in acute myeloid leukemia and myelodysplastic syndromes. J Mol Diagn 2015;17:661-668. 
32 Chou WC, Hou HA, Chen CY, Tang JL, Yao M, Tsay W, Ko BS, Wu SJ, Huang SY, Hsu SC, Chen YC, Huang YN, Chang YC, Lee FY, Liu MC, Liu CW, Tseng MH, Huang CF, Tien HF: Distinct clinical and biologic characteristics in adult acute myeloid leukemia bearing the isocitrate dehydrogenase 1 mutation. Blood 2010;115:2749-2754.

33 Caramazza D, Lasho TL, Finke CM, Gangat N, Dingli D, Knudson RA, Siragusa S, Hanson CA, Pardanani A, Ketterling RP, Tefferi A: IDH mutations and trisomy 8 in myelodysplastic syndromes and acute myeloid leukemia. Leukemia 2010;24:2120-2122.

34 Feng JH, Guo XP, Chen YY, Wang ZJ, Cheng YP, Tang YM: Prognostic significance of IDH1 mutations in acute myeloid leukemia: a meta-analysis. Am J Blood Res 2012;2:254264.

35 Xu Q, Li Y, Lv N, Jing Y, Xu Y, Li Y, Li W, Yao Z, Chen X, Huang S, Wang L, Li Y, Yu L: Correlation between isocitrate dehydrogenase gene aberrations and prognosis of patients with acute myeloid leukemia: a systematic review and meta-analysis. Clin Cancer Res 2017;23:4511-4522.
36 Zhou KG, Jiang LJ, Shang Z, Wang J, Huang L, Zhou JF: Potential application of $I D H 1$ and IDH2 mutations as prognostic indicators in non-promyelocytic acute myeloid leukemia: a meta-analysis. Leuk Lymphoma 2012;53: 2423-2429.

37 Lin TL, Nagata Y, Kao HW, Sanada M, Okuno Y, Huang CF, Liang DC, Kuo MC, Lai CL, Lee EH, Shih YS, Tanaka H, Shiraishi Y, Chiba K, Lin TH, Wu JH, Miyano S, Ogawa S, Shih LY: Clonal leukemic evolution in myelodysplastic syndromes with TET2 and IDH1/2 mutations. Haematologica 2014;99:28-36.

38 Zhao S, Lin Y, Xu W, Jiang W, Zha Z, Wang P, Yu W, Li Z, Gong L, Peng Y, Ding J, Lei Q, Guan KL, Xiong Y: Glioma-derived mutations in IDH1 dominantly inhibit IDH1 catalytic activity and induce HIF-1a. Science 2009;324:261-265.

39 Tong H, Hu C, Zhuang Z, Wang L, Jin J: Hypoxia-inducible factor-1 $\alpha$ expression indicates poor prognosis in myelodysplastic syndromes. Leuk Lymphoma 2012;53:24122418.

40 Khan H, Vale C, Bhagat T, Verma A: Role of DNA methylation in the pathogenesis and treatment of myelodysplastic syndromes. Semin Hematol 2013;50:16-37.

41 Molenaar RJ, Radivoyevitch T, Maciejewski JP, van Noorden CJ, Bleeker FE: The driver and passenger effects of isocitrate dehydrogenase 1 and 2 mutations in oncogenesis and survival prolongation. Biochim Biophys Acta 2014;1846:326-341.
42 Molenaar RJ, Thota S, Nagata Y, Patel B, Clemente M, Przychodzen B, Hirsh C, Viny AD, Hosano N, Bleeker FE, Meggendorfer M, Alpermann T, Shiraishi Y, Chiba K, Tanaka $\mathrm{H}$, van Noorden CJ, Radivoyevitch T, Carraway HE, Makishima H, Miyano S, Sekeres MA, Ogawa S, Haferlach T, Maciejewski JP: Clinical and biological implications of ancestral and non-ancestral IDH1 and IDH2 mutations in myeloid neoplasms. Leukemia 2015; 29:2134-2142.

43 Stein EM, DiNardo CD, Pollyea DA, Fathi AT, Roboz GJ, Altman JK, Stone RM, DeAngelo DJ, Levine RL, Flinn IW, Kantarjian HM, Collins R, Patel MR, Frankel AE, Stein A, Sekeres MA, Swords RT, Medeiros BC, Willekens C, Vyas P, Tosolini A, Xu Q, Knight RD, Yen KE, Agresta S, de Botton S, Tallman MS: Enasidenib in mutant $\mathrm{IDH} 2$ relapsed or refractory acute myeloid leukemia. Blood 2017; 130:722-731.

44 Boddu P, Borthakur G: Therapeutic targeting of isocitrate dehydrogenase mutant AML. Expert Opin Investig Drugs 2017;26:525-530. 